\title{
Cultivating spiritual resources for improving undergraduate students' mental health
}

\author{
IrwanNuryana Kurniawan 1 \\ ${ }_{1}^{1}$ Psychology Department,Universitas Islam Indonesia, Yogyakarta,Indonesia 1 \\ *(e-mail) kurniawan-in@uii.ac.id
}

\begin{abstract}
The increasing number of students coming to the university's guidance and counseling unit demonstrates the need for more serious and systemic efforts to deal with students' mental health. Previous studies have shown that religion has significant contribution to the human mental health and psychological well-being. This study specifically examined the role of one of the spiritual resources that get emphasis in Islamic teachings that is "Tawakal toward Allah Subhanahu wa Ta'ala" to the undergraduate students' mental health. To test the research hypothesis that asserted there is a positive relationship between surrender to God and social-emotional health, current study uses correlational design. The study involved 57 undergraduate students of the statistic class at Psychology Department of Islamic University of Indonesia, Yogyakarta and Surrender to God Scale (Wong-McDonald \& Gorsuch, 2000)and Social-Emotional Health Survey (Furlong, You, Shishim, \& Dowdy, 2017) were administered to them. When social desirability on the relationship between surrender to God and social-emotional health was controlled, partial correlation $r(56)=.510, p=.001$ was found. The result suggests that there was a significant and strongly positive association between surrender to God and students' social-emotional health when controlling social desirability scores.
\end{abstract}

Keywords: Surrender to God, Social-Emotional Health, Undergraduate students.
Received February 05, 2018; Revised Februaray 15, 2018; Accepted Februaray 20, 2018; Published Online March 30, 2018

\section{Conflict of Interest Disclosures:}

The authors declare that they have no significant competing financial, professional or personal interests that might have influenced the

performance or presentation of the work described in this manuscript.

\section{Introduction}

Although all higher education institutions recognize and consider the importance of mental health for the success of their student studies, some universities (Clapham, Jahchan, Medves, Tierney, \& Walker, 2012; Report, 2008) report that mental health is still a concerning issue on their campus. The problems ranging from stress, anxiety, until diagnosed depression disorder (Beiter et al., 2014; Hussain, Guppy, Robertson, \& Temple, 2013; Macaskill, 2012). Whereas mental health problems such as depression related to poor quality in behaviour, social relationships, and academic performance of undergraduate students(Keyes, 2009). Likewise, stress is found to have negative impact on physical health, mental health, and academic achievement(Shankar \& Park, 2016). 
In contrast to the above studies that view mental health as the absence of disease, disorder, and disability, current research uses positive mental health concept than emphasizes more on the presence of assets, strengths, and positive attributes. Individual free of mental illness are not necessarily mentally healthy(Keyes, 2009, 2014). In other words, affirming that problem-free does not mean fully prepared (Pittman, 1992). In fact, the concept of positive mental health was adopted by World Health Organization (WHO) and now mental health is defined as a state of well-being in which individual realizes his or her own abilities, can cope with the normal of stresses of life, can work productively and fruitfully, and is able to make a contribution to his or her community (World Health Organization, 2004).

\section{Method}

In the Method section, you explain clearly how you conducted your studyin order to: (1) enable readers to evaluate the work performed and (2) permit others toreplicate your study. You must describe exactly what you did: what and how experiments were run, what,how much, how often, where, when, and why equipment and materials were used. Themain consideration is to ensure that enough detail is provided to verify your findings andto enable the replication of the study.You should maintain a balance between brevity (you cannot describe every technicalissue) and completeness (you need to give adequate detail so that readers know whathappened).

\section{Best Practice:}

Define the population and the method of sampling;

Describe the instrumentation;

Describe the procedures and if relevant, the time frame;

Describe the analysis plan;

Describe any approaches to ensure validity and reliability;

State any assumptions;

Describe statistical tests and the comparisons made; ordinary statistical methods should be used without comment; advanced or unusual methods may require aliterature citation, and;

Describe the scope and/or limitations of the methodology you used.

In the social and behavioral sciences, it is important toal ways provide sufficientin formation to allow other research erstoad optorreplicate your methodology. This information isparticularly important when a new method has been developed or an innovative use of an exisiting method isutilized. Last, please avoid to make a sub section in Method.

\section{Results and Discussion}

Tabel 1

\begin{tabular}{|c|c|c|c|c|}
\hline Control Variables & & & Social_Emotional_Health & Surrender_to_God \\
\hline \multirow[t]{6}{*}{ Social_Desirability } & Social_Emotional_Health & Correlation & 1.000 & .510 \\
\hline & & $\begin{array}{l}\text { Significance (1- } \\
\text { tailed) }\end{array}$ & . & .000 \\
\hline & & $\mathrm{df}$ & 0 & 56 \\
\hline & Surrender_to_God & Correlation & .510 & 1.000 \\
\hline & & $\begin{array}{l}\text { Significance (1- } \\
\text { tailed) }\end{array}$ & .000 & . \\
\hline & & $\mathrm{df}$ & 56 & 0 \\
\hline
\end{tabular}

Tabel 2 
Correlations with Undergraduate Femate Students

\begin{tabular}{|c|c|c|c|c|}
\hline Control Variables & & & $\begin{array}{c}\text { Social_Emotiona } \\
\text { 1_Health }\end{array}$ & $\begin{array}{c}\text { Surrender_to_G } \\
\text { od }\end{array}$ \\
\hline \multirow[t]{6}{*}{ Social_Desirability } & Social_Emotional_He & Correlation & 1.000 & .654 \\
\hline & alth & Significance (1-tailed) & . & .000 \\
\hline & & $\mathrm{df}$ & 0 & 40 \\
\hline & Surrender_to_God & Correlation & .654 & 1.000 \\
\hline & & Significance (1-tailed) & .000 & \\
\hline & & $\mathrm{df}$ & 40 & 0 \\
\hline
\end{tabular}

Tabel 3

Correlations with Undergraduate Male Students

\begin{tabular}{|c|c|c|c|c|}
\hline Control Variables & & & $\begin{array}{c}\text { Social_Emotiona } \\
\text { 1_Health }\end{array}$ & $\begin{array}{c}\text { Surrender_to_G } \\
\text { od }\end{array}$ \\
\hline \multirow[t]{6}{*}{ Social_Desirability } & Social_Emotional_He & Correlation & 1.000 & .232 \\
\hline & alth & Significance (1-tailed) & . & .203 \\
\hline & & df & 0 & 13 \\
\hline & Surrender_to_God & Correlation & .232 & 1.000 \\
\hline & & Significance (1-tailed) & .203 & \\
\hline & & $\mathrm{df}$ & 13 & 0 \\
\hline
\end{tabular}

\section{Conclusion}

Undergraduate students' mental health variability can be significantly explained by the surrender to God variability. The strength of the relationship between surrender to God and undergraduate students' mental health varies according to gender factors

\section{Acknowledgment}

Many thanks to all statistic class students who volunteer to participate in this research project. RidhaHabibah and Izdatunnida who has helped me much with thestudy, and Hasan Mangkualamwho provided technical help.

\section{References}

Beiter, R., Nash, R., Mccrady, M., Rhoades, D., Linscomb, M., Clarahan, M., \& Sammut, S. (2014). The prevalence and correlates of depression, anxiety, and stress in a sample of college students. Journal of Affective Disorders, 173, 90-96. https://doi.org/10.1016/j.jad.2014.10.054.

Clapham, L., Jahchan, R., Medves, J., Tierney, A., \& Walker, D. (2012). Student mental health and wellness: Framework and recommendations for a comprehensive strategy. Retrieved from http://www.queensu.ca/principal/sites/webpublish.queensu.ca.opvcwww/files/files/CMHFinalRe port.pdf. 
Furlong, M. J., You, S., Shishim, M., \& Dowdy, E. (2017). Development and validation of the Social Emotional Health Survey-Higher Education Version. Applied Research in Quality of Life, 12(2), 343367. https://doi.org/10.1007/s11482-016-9464-9.

Hussain, R., Guppy, M., Robertson, S., \& Temple, E. (2013). Physical and mental health perspectives of first year undergraduate rural university students. BMC Public Health, 13, 1. https://doi.org/10.1186/1471-2458-13-848.

Keyes, C. L. M. (2009). The nature and importance of mental health in America's adolescence. In M. J. Furlong, R. Gilman, \& E. S. Huebner (Eds.), Handbook of Positive Psychology in Schools (pp. 9-25). New York: Routledge. Retrieved from https://books.google.co.id/books?hl=en\&lr=\&id=1pKOAgAAQBAJ\&oi=fnd\&pg=PA9\&dq=The+ nature + and + importance + of + positive + mental + health + in + America $\% 27 \mathrm{~s}+$ adolescence $\&$ ots $=9 \mathrm{KnMm}$ nBK94\&sig=7d7GDOZk5G62CICh6a9X3I7r7rU\&redir_esc=y\#v=onepage\&q=The nature and importan.

Keyes, C. L. M. (2014). Mental health as a complete state: How the salutogenic perspective completes the picture. In G. . Bauer \& O. Hämmig (Eds.), Bridging occupational, organizational and public health: A transdisciplinary approach (pp. 179-192). Springer Science. https://doi.org/10.1007/978-94-007-56403_11.

Macaskill, A. (2012). The mental health of university students in the United Kingdom. British Journal of Guidance and Counselling, 41(4), 426-441. Retrieved from http://shura.shu.ac.uk/6449/.

Pittman, K. (1992). Let's make youth work a field. Retrieved February 8, 2018, from http://forumfyi.org/content/youth-today-lets-make-.

Report, T. F. (2008). Student mental health and well-being. Stanford, CA . Retrieved from https://wellness.stanford.edu/sites/default/files/taskforce_report.pdf.

Shankar, N. L., \& Park, C. L. (2016). Effects of stress on students' physical and mental health and academic success. International Journal of School \& Educational Psychology, 4(1), 5-9. https://doi.org/10.1080/21683603.2016.1130532.

Wong-McDonald, A., \& Gorsuch, R. L. (2000). Surrender to God: An additional coping style? Journal of Psychology and Theology, 28(2), 149-161.

World Health Organization. (2004). Promoting mental health: Concepts, emerging evidence, and practice. Geneva. Retrieved from http://www.who.int/mental_health/evidence/en/promoting_mhh.pdf. 